\title{
Living mulch strategy for organic cauliflower (Brassica oleracea L.) production in central and southern Italy
}

\author{
Stefano Canali, ${ }^{1}$ Gabriele Campanelli, ${ }^{2}$ Corrado Ciaccia, ${ }^{1}$ Mariangela Diacono, ${ }^{3}$ \\ Fabrizio Leteo, ${ }^{2}$ Angelo Fiore, ${ }^{4}$ Francesco Montemurro ${ }^{4}$ \\ ${ }^{1}$ Centro per lo Studio delle Relazioni tra Pianta e Suolo, Consiglio per la Ricerca e I'Analisi \\ dell'Economia Agraria, Roma; ${ }^{2}$ Unità di Ricerca per l'Orticoltura, Consiglio per la Ricerca e \\ l'Analisi dell'Economia Agraria, Monsampolo del Tronto (AP); ${ }^{3}$ Unità di Ricerca per i \\ Sistemi Colturali degli Ambienti Caldo-Aridi, Consiglio per la Ricerca e l'Analisi \\ dell'Economia Agraria, Bari; ${ }^{4}$ Unità di Ricerca per i Sistemi Colturali degli Ambienti \\ Caldo-Aridi, Consiglio per la Ricerca e l'Analisi dell'Economia Agraria, \\ Azienda Sperimentale Metaponto (MT), Italy
}

\begin{abstract}
In sustainable agricultural systems, intercropping using living mulches (LM) provides many beneficial ecosystem services. The objective of these two-year field experiments was to study the suitability of different LM options of burr medic (Medicago polymorpha L. var. anglona) for organic cauliflower (Brassica oleracea L.) cultivation in two sites under Mediterranean conditions. In central Italy (Experiment 1) contemporary and delayed (to crop) sowings of LM were compared with a no-cover crop treatment, contrasting two local cauliflower cultivars and a F1 Hybrid. In southern Italy (Experiment 2) the sustainability of systems combining LM (anticipated and contemporary sowing compared with no-cover) and organic fertilisation strategies was assessed. The aboveground biomasses dry weights of cauliflower crop (heads and residues), burr medic and weeds were separately determined. Results suggested that in Experiment 1 the LM was not able to
\end{abstract}

\footnotetext{
Correspondence: Mariangela Diacono, Unità di Ricerca per i Sistemi Colturali degli Ambienti Caldo-Aridi, Consiglio per la Ricerca e l'Analisi dell'Economia Agraria, via Celso Ulpiani 5, 70125 Bari, Italy.

Tel.: +39.0805475252 - Fax: +39.0805475023.

E-mail: mariangela.diacono@entecra.it
}

Key words: Agroecology; agro-ecological services; cauliflower genotypes; cover crops; organic fertilisers.

Conference presentation: SIA XLIII Congress, Pisa, 2014.

Received for publication: 19 December 2014.

Revision received: 4 February 2015.

Accepted for publication: 7 February 2015.

(C) Copyright S. Canali et al., 2015

Licensee PAGEPress, Italy

Italian Journal of Agronomy 2015; 10:644

doi:10.4081/ija.2015.644

This article is distributed under the terms of the Creative Commons Attribution Noncommercial License (by-nc 3.0) which permits any noncommercial use, distribution, and reproduction in any medium, provided the original author(s) and source are credited. smother weeds establishment and growth, as a consequence of early sowing, while cauliflower yield was reduced. Moreover, the genotypes behaviour was greatly influenced by the LM sowing times. In Experiment 2, irrespective of the agronomic practices applied, climatic conditions notably influenced cauliflower cultivation and also reduced the mean yield. Therefore, the recorded differences between the two experimental sites highlighted the need to tailor the LM strategies to the different environmental conditions.

\section{Introduction}

The use of cover crops within crop rotations in horticultural systems has been recently rediscovered by farmers as a valuable agronomic practice according to an agro-ecological approach (Campiglia et al., 2011; Wezel et al., 2014). In particular, cover crops sown either before or with a main crop, and maintained as a living ground cover throughout the growth cycle, can provide fundamental services to the agroecosystem, thus they can be defined agro-ecological service crops (ASC). The ASC grown as living mulch tie up excess soil nutrients, preventing nitrate leaching, improve soil physical characteristics (Carof et al., 2007), promote in-field biodiversity (Fageria et al., 2005), suppress weeds (Teasdale et al., 2007; Bilalis et al., 2010), add organic matter to soil (Mazzoncini et al., 2011), contribute in reducing surface water runoff and losses of nutrients and pesticides (Hartwig and Ammon, 2002). Moreover, the use of leguminous ASC that fix nitrogen from the atmosphere could further improve resource use efficiency in the cropping system (Wezel et al., 2014). Among leguminous LM, in particular self-reseeding annual legumes (such as Medicago spp.) that are able to persist over several years without the need for reseeding, can play an important role in Mediterranean organic farming systems (Driouech et al., 2008). In any case, the success of living mulch systems depends on the capacity to rapidly establish a ground cover without competing for resources (light, water, and nutrients) with the associated crop (Masiunas, 1998).

To the best of our knowledge, there are no scientific evidences about the effectiveness of the above-described ecosystem services linked to LM for organic vegetables in different sites under Mediterranean conditions. Therefore, the objective of these two-year field experiments was to study the suitability of different intercropping systems of organic cauliflower (Brassica oleracea L.var. botrytis) with burr medic (Medicago polymorpha L.) continuous cover, in two differ- 
ent sites in Mediterranean environment. In particular, since information about the agronomic performances of different cauliflower genotypes in organic farming under different intercropping systems are missing, a comparison between two local cauliflower cultivars and a F1 Hybrid was carried out at Monsampolo del Tronto-AP (central Italy). Our hypothesis was that the local cauliflower cultivars could obtain higher yield than the F1 Hybrid and reduce weed presence, due to their better environmental adaptation. Moreover, since vegetable crops often have high nutrient demand and low efficiency of nutrient utilisation, then at Metaponto-MT (southern Italy) the sustainability and crop performance of different intercropping systems combined with organic fertilisation strategies to improve crop performance and weed suppression was assessed.

\section{Materials and methods}

\section{Study sites and experimental setup}

The research was carried out during 2010-2011 and 2011-2012 seasons (indicated as 2011 and 2012, respectively) in two sites: i) at Monsampolo del Tronto, in central Italy (lat $42^{\circ} 53^{\prime} \mathrm{N}$, long $13^{\circ} 48^{\prime} \mathrm{E}$ ), at the MOnsampolo VEgetable organic long-term field experiment (MOVE-LTE) located in the CRA-Research unit for vegetable production (CRA-ORA); ii) at Metaponto (MT), in Southern Italy (lat. $40^{\circ} 24^{\prime} \mathrm{N}$; long. $16^{\circ} 48^{\prime} \mathrm{E}$ ), in the research farm Azienda Sperimentale Metaponto of the CRA-Research Unit for Cropping Systems in Dry Environments [CRA-SCA (ASM)].

\section{Experiment 1}

The Monsampolo site is characterised by a thermomediterranean climate (UNESCO-FAO, 1963). Monthly values of mean temperatures and total rainfall during the field trial, compared to the average long-term values (30 years) are reported in Figure 1A. According to the soil taxonomy of the U.S. Department of Agriculture (Soil Survey Staff, 1999), the soil is Typic Calcixerepts fine-loamy, mixed thermic. The MOVE-LTE is based on a four-year crop rotation with different cover crops and it was established in 2001. More details about the study site at MOVE-LTE are available in Campanelli and Canali (2012).

The experimental design was a split-plot with two factors and three replications. Each elementary plot consisted of $16.8 \mathrm{~m}^{2}$. The main plot factor was the living mulch (Medicago polymorpha L. cv. anglona) sowing time strategy and the following two different treatments were compared: i) early sowing (concomitant to cauliflower transplanting, CON); and ii) late sowing (three weeks after cauliflower transplanting, POS). These experimental treatments were compared to a no living mulch control (NL). The NL treatment was managed in accordance to the standard agronomic practices (i.e., weeded through two hoeing during the crop cycle) commonly used by organic farmers in the area, whereas no weeding was performed in the CON and POS treatments. The split plot factor was cauliflower genotype with three levels: Emeraude F1 Hybrid (EM), cvl and cv2 (open-pollinated, locally adapted cultivars). Each treatment was repeated in triplicate. The cauliflower crop was manually transplanted in August in both cropping cycles. The harvest started on November $24^{\text {th }}$ and ended on December $28^{\text {th }}$ in the first year, whereas it started on December $16^{\text {th }}$ and ended on February $23^{\text {rd }}$ in the second trial year.

\section{Experiment 2}

The Metaponto site is characterised by an accentuated thermomediterranean climate (UNESCO-FA0, 1963). Mean monthly temperatures and rainfall during the field trial, compared to the average long- term values (30 years), are reported in Figure 1B. According to the soil taxonomy of the U.S. Department of Agriculture (Soil Survey Staff, 1999), the soil is Typic Epiaquert.

The experimental design was a strip-plot with two factors and three replications (blocks); each elementary plot consisted of $20 \mathrm{~m}^{2}$. The living mulch (Medicago polymorpha L. var. anglona) sowing strategy was the main factor and the following treatments were compared: i) anticipated sowing (AS; 20 days before cauliflower transplanting); and ii) contemporary sowing (CS; concomitant to cauliflower transplanting). These experimental treatments were compared to a no living mulch control (NL). No weeding was performed in all the compared treatments. Each LM plot was split in four sub-plots, each of which associated to one of the following organic fertilisers, allowed in organic farming: i) a commercial humified fertiliser, based on dried animal manure (Org); ii) anaerobic digestate fertiliser, based on wine distillery wastewater (WDD); iii) composted municipal solid organic wastes from separate collection (SUW); and an unfertilised control (N0). Additional information about both the WDD and SUW production processes are reported in Montemurro et al. (2013). The organic materials (the same in both years) were applied to soil in one solution about 1 month before transplanting of cauliflower, at the rate of $100 \mathrm{~kg} \mathrm{~N} \mathrm{ha}^{-1}$ in AS and CON, compared to $200 \mathrm{~kg} \mathrm{~N} \mathrm{ha}^{-1}$ in NL by taking into account the potential contribution of burr medic biological $\mathrm{N}$ fixation in the first two treatments.

The cauliflower crop (cv Triunphan) was manually transplanted on September and October in 2011 and 2012, respectively, and it was harvested on March $8^{\text {th }} 2011$ and on March $28^{\text {th }} 2012$.

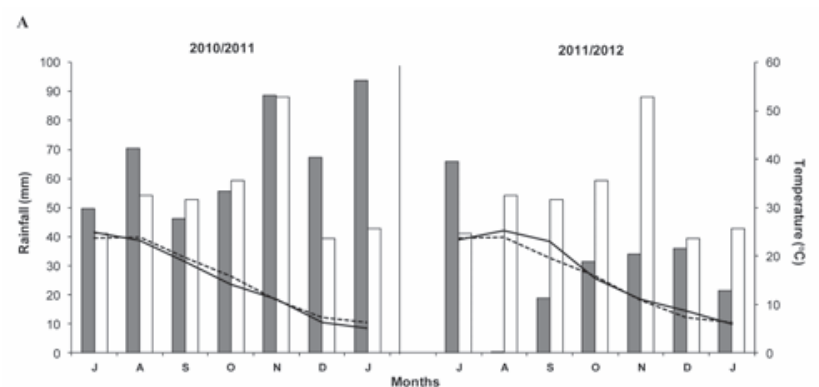

B

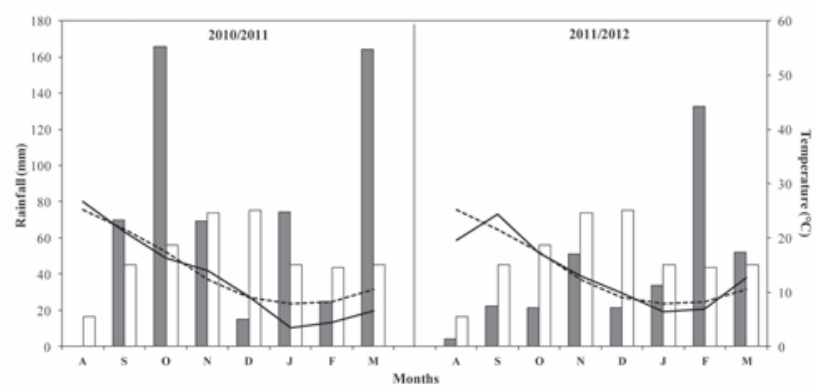

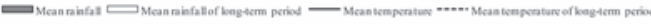

Figure 1. Weather conditions (monthly values of mean temperatures and total rainfall) recorded during the cauliflower growing seasons (2010-2011 and 2011-2012) at Experiment 1, Monsampolo site (A) and at Experiment 2, Metaponto site (B). The values are compared to monthly mean values of rainfall and temperatures processed over a 30-year time. 
Measurements and statistical analysis

At harvesting, in each experimental site cauliflower heads were collected on plants selected in the middle of the plots. The aboveground biomass weights of cauliflower crop (heads and residues), burr medic and weeds were separately measured in all plots, then they were dried at $105^{\circ} \mathrm{C}$ till constant weight and weighted again in order to determine their dry weights.

The analysis of variance (ANOVA) over the two years was carried out for both sites, considering living mulch management, genotype/fertiliser and year as factors. To compare the differences obtained, means were further analysed by Tukey's HSD test $(\mathrm{P}<0.05)$. The selected analyses were performed by using the SPSS 16.0 package.

\section{Results}

\section{Comparison between the two trial years in each experimental site}

Over the period July-January at the site of Experiment 1 (Figure 1A), in 2011 the total rainfall $(472 \mathrm{~mm}$ ) was higher than the long-term average (about $377 \mathrm{~mm}$ ), whereas it was lower in 2012 (208 $\mathrm{mm})$. A substantial difference between years was also found for the mean temperature, which was lower in the first crop cycle $\left(14.7^{\circ} \mathrm{C}\right)$ and higher in the second one $\left(16.1^{\circ} \mathrm{C}\right)$, as compared to the long-term average $\left(15.4^{\circ} \mathrm{C}\right)$.

At the site of Experiment 2 (Figure 1B), over the period September-

Table 1. Analysis of variance of the effect of living mulch strategies and cauliflower genotypes on crop yield and residues, weeds and medic for the two research years in Experiment 1.

\begin{tabular}{lcccc} 
& Yield & Residues & Weeds & Burr medic \\
Year (Y) & $* *$ & $* * *$ & $* *$ & $* * *$ \\
Living mulch (LM) & $* * *$ & $* * *$ & $* *$ & $* *$ \\
\hline Genotype (G) & $* * *$ & n.s. & n.s. & $* * *$ \\
Y x LM & $* * *$ & $*$ & $* *$ & $* * *$ \\
\hline Y x G & $* * *$ & $* * *$ & $n . s$. & $* *$ \\
LM x G & $* * *$ & n.s. & n.s. & n.s. \\
\hline Yx LM x G & $* * *$ & n.s. & n.s. & $* *$
\end{tabular}

The probability levels are presented by years, living mulch strategies, genotypes and their interactions. *, **, ${ }^{* *}$ Significant at the $\mathrm{P}<0.05, \mathrm{P}<0.01$ and $\mathrm{P}<0.001$, respectively. n.s., not significant.

Table 2. Analysis of variance of the effect of living mulch strategies and fertilisers on crop yield and residues, weeds and burr medic for the two research years in Experiment 2.

\begin{tabular}{lcccc} 
& Yield & Residues & Weeds & Burr medic \\
Year (Y) & $* *$ & n.s. & $* * *$ & $*$ \\
Living mulch (LM) & $* * *$ & n.s. & $* * *$ & n.s. \\
\hline Fertiliser (F) & n.s. & n.s. & n.s. & n.s. \\
Yx LM & $* *$ & $* *$ & $* * *$ & $* *$ \\
\hline Y x F & n.s. & $*$ & n.s. & n.s. \\
LM x F & n.s. & n.s. & n.s. & n.s. \\
\hline Yx LM x F & n.s. & n.s. & n.s. & n.s.
\end{tabular}

The probability levels are presented by years, living mulch strategies, fertilisers and their interactions. ${ }^{*},{ }^{* *},{ }^{* * *}$ Significant at the $\mathrm{P}<0.05, \mathrm{P}<0.01$ and $\mathrm{P}<0.001$, respectively. n.s., not significant.
March, in 2011 the total rainfall (583 $\mathrm{mm}$ ) was notably higher than the long-term average (about $384 \mathrm{~mm})$, whereas it was lower in 2012 (335 $\mathrm{mm})$. The mean temperature was lower in the first crop cycle $\left(10.7^{\circ} \mathrm{C}\right)$ and slightly higher in the second one $\left(12.9^{\circ} \mathrm{C}\right)$, as compared to the average $\left(12.4^{\circ} \mathrm{C}\right)$.

The outputs of ANOVA, considering the 3 experimental factors (year; living mulch; genotype or fertiliser) and their interactions, are reported in Tables 1 and 2 for crop yield as well as residues, weeds and burr medic dry biomasses at Experiment 1 and 2, respectively.

In particular year, living mulch strategy and genotypes (Table 1) generally revealed significant main effects on the examined variables; however, genotypes did not affect residues and weeds. Moreover, significant three-way interactions were found for both yield and burr medic biomass. In Table 2 significant main effects of year (except for residues) and living mulch (except for residues and burr medic) are shown. In addition, year $\mathrm{x}$ living mulch interactions were all significant, whereas significant year $\mathrm{x}$ fertiliser interaction was found only for residues. According to the prevailing significance of year factor, data were analysed splitting the two years.

\section{Crop performance}

The ANOVA results are reported in Table 3 (for Experiment 1) and 4 (for Experiment 2). Within the Experiment 1, the living mulch treatments showed significant differences both in 2011 and 2012 cropping seasons, for crop yield and residues (Table 3). In particular, POS treatment showed the highest cauliflower yield in 2011, 29.8\% and $28.1 \%$ higher than NL and CON, respectively. Moreover, POS and NL showed

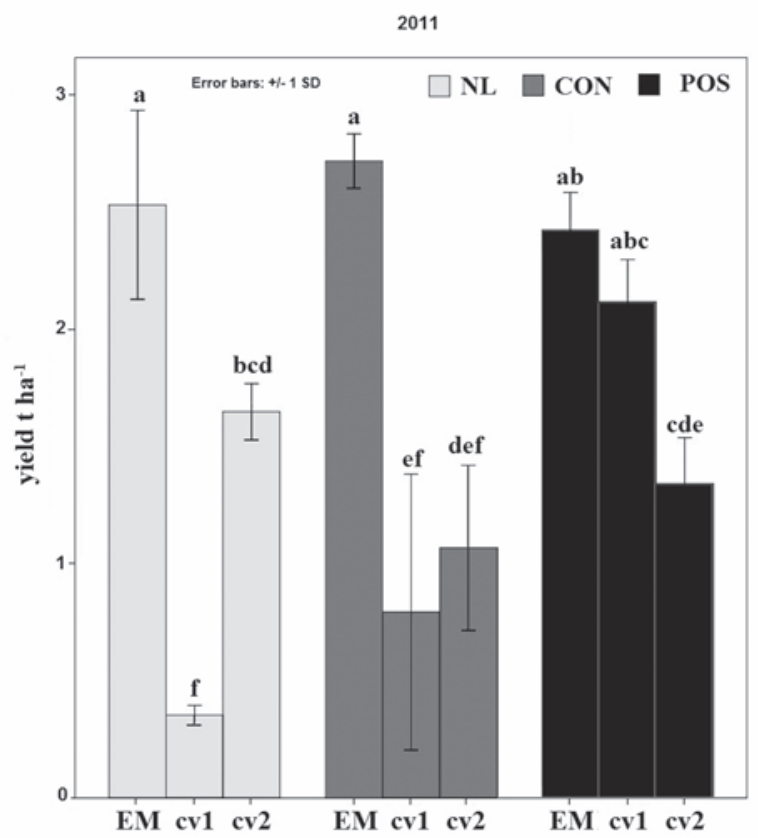

Figure 2. Effect of the interaction between living mulch management strategies and cauliflower genotypes on cauliflower yield $(t$ $h^{-1}$ ) in 2011 trial year. The bars with different letters are significantly different $(P<0.05)$. NL, no living mulch control; CON, early sowing, at cauliflower transplanting; POS, late sowing, three weeks after cauliflower transplanting; EM, Emeraude F1 Hybrid; cv1 and cv2, open-pollinated, locally adapted cultivars. 
higher crop residues dry biomass than CON. As for the significant interaction between LM and genotype, the EM genotype determined the highest yield, as compared to the two local cultivars, even if it was not significantly different from cvl within POS treatment (Figure 2). From the comparison among the LM within each genotype, no significant differences were recorded for EM and cv2, whereas the combinations of cvl with POS and NL resulted in the highest and lowest yield, respectively. In 2012, a reduction of mean yield and residues was found, although POS confirmed higher yield value (over 100\%) compared to CON, but not different from NL (Table 3). In addition, the POS and NL strategies did not significantly differ from each other as for residues, and they both showed significantly higher values than CON. The EM genotype determined the highest residues biomass (86\% and $49 \%$ higher than cvl and cv2, respectively).

At Experiment 2, the living mulch treatments determined significant differences for yield and residues only in 2011 (Table 4). In particular, both AS and CS treatments showed significantly higher yields than NL, but also greater residues values (by 120\%) were found in CS treatment as compared to NL, while AS showed intermediate values. Moreover, Org yield was $111 \%$ higher than the average production provided by $\mathrm{N} 0$ and WDD fertiliser treatments, but it was not significantly different from SUW.

\section{Effects of living mulch, genotype and fertilisers on weeds and burr medic biomasses}

At Experiment 1, in 2011 CON treatment showed a 176\% higher weeds biomass than POS, whereas NL had intermediate value (Table 3). In $2012 \mathrm{NL}$ and POS treatment effects were inverted. The genotype factor determined significant differences only in 2011 cropping season, when EM showed the lowest values. In particular, the EM-CON combination had significantly lower values than cv2-CON interaction $(0.06 \mathrm{t}$ $\mathrm{ha}^{-1}$ vs $0.88 \mathrm{t} \mathrm{ha}^{-1}$, respectively) (Figure 3). In this year, CON showed burr medic biomass significantly higher by $155 \%$ than POS, and EM determined the lowest value among genotypes. In 2012 the same parameter was not significantly different between EM and cvl. In Figure 4 it is reported the effect of interaction between living mulch strategies and cauliflower genotypes on burr medic in 2011. The highest biomass (2.59 $\left.\mathrm{t} \mathrm{ha}^{-1}\right)$ was found for cvl-CON combination, whereas EM showed the lowest values both in combination with $\operatorname{CON}\left(0.31 \mathrm{t} \mathrm{ha}^{-1}\right)$ and POS $\left(0.21 \mathrm{t} \mathrm{ha}^{-1}\right)$ treatments.

At Experiment 2, in 2011 NL determined weeds biomass significantly and notably higher than both AS and CS treatments (Table 4). In the same year, AS showed burr medic biomass significantly higher by $62 \%$ than CS treatment. Conversely, in 2012 the higher value was found in CS (by 73\%) as compared to AS treatment.

Table 3. Effect of living mulch strategies and cauliflower genotypes on crop yield $\left(t \mathrm{ha}^{-1}\right)$, residues $\left(\mathrm{t} \mathrm{ha} \mathrm{a}^{-1}\right)$, weeds $\left(\mathrm{t}\right.$ ha $\left.{ }^{-1}\right)$ and burr medic $\left(\mathrm{tha}^{-1}\right)$ at Experiment 1 in each trial year.

\begin{tabular}{|c|c|c|c|c|c|c|c|c|c|c|}
\hline & & Living & h (LM & & & & lotype & & & \\
\hline & NL & $\mathrm{CON}$ & POS & P value & EM & cvl & cv2 & Mean & P value & LM x G \\
\hline 2011 & & & & & & & & & & \\
\hline Yield & $1.51^{b}$ & $1.53^{b}$ & $1.96^{\mathrm{a}}$ & $* * *$ & $2.56^{\mathrm{a}}$ & $1.09^{b}$ & $1.35^{\mathrm{b}}$ & 1.67 & $* *$ & $*$ \\
\hline Residues & $7.85^{\mathrm{a}}$ & $4.89^{b}$ & $8.68^{\mathrm{a}}$ & $* * *$ & 6.57 & 7.74 & 7.11 & 7.14 & n.s. & n.s. \\
\hline Weeds & $0.26^{\mathrm{ab}}$ & $0.36^{\mathrm{a}}$ & $0.13^{b}$ & $* *$ & $0.07^{\mathrm{b}}$ & $0.25^{\mathrm{a}}$ & $0.12^{\mathrm{a}}$ & 0.13 & $* * *$ & $* * *$ \\
\hline Burr medic & - & $1.56^{\mathrm{a}}$ & $0.61^{\mathrm{b}}$ & $* * *$ & $0.26^{\mathrm{b}}$ & $1.68^{\mathrm{a}}$ & $1.32^{\mathrm{a}}$ & 1.09 & $* * *$ & $* *$ \\
\hline 2012 & & & & & & & & & & \\
\hline Yield & $1.87^{\mathrm{a}}$ & $0.73^{b}$ & $1.68^{\mathrm{a}}$ & $* * *$ & 1.89 & 1.21 & 1.35 & 1.43 & n.s. & n.s. \\
\hline Residues & $7.02^{\mathrm{a}}$ & $1.81^{\mathrm{b}}$ & $6.21^{\mathrm{a}}$ & $* * *$ & $6.81^{\mathrm{a}}$ & $3.66^{\mathrm{b}}$ & $4.57^{\mathrm{b}}$ & 5.01 & $* * *$ & n.s. \\
\hline Weeds & $0.14^{\mathrm{b}}$ & $2.01^{\mathrm{a}}$ & $0.78^{\mathrm{ab}}$ & $* *$ & 0.48 & 1.22 & 1.22 & 0.97 & n.s. & n.s. \\
\hline Burr medic & - & 0.42 & 0.64 & n.s. & $0.23^{b}$ & $0.40^{\mathrm{ab}}$ & $0.96^{\mathrm{a}}$ & 0.53 & $*$ & n.s. \\
\hline
\end{tabular}

NL, control (no living mulch); CON, early sowing (at cauliflower transplanting); POS, late sowing (three weeks after cauliflower transplanting); EM, Emeraude F1 Hybrid; cvl and cv2, open-pollinated, locally adapted cultivars; n.s., not significant. a,bMeans of living mulch strategies and cauliflower genotypes followed by different letters within rows are significantly different $(\mathrm{P}<0.05) .{ }^{*},{ }^{* *},{ }^{* * *}$ Significant at the $\mathrm{P}<0.05, \mathrm{P}<0.01$ and $\mathrm{P}<0.001$, respectively.

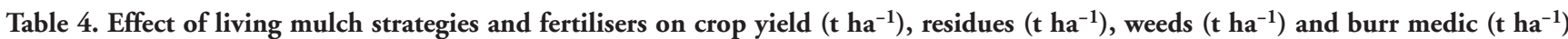
at Experiment 2 in each trial year.

\begin{tabular}{|c|c|c|c|c|c|c|c|c|c|c|c|}
\hline & \multicolumn{4}{|c|}{ Living mulch (LM) } & \multicolumn{6}{|c|}{ Fertiliser (F) } & \multirow[b]{2}{*}{ LM $\mathrm{x}$} \\
\hline & NL & AS & CS & P value & NO & SUW & WDD & Org & Mean & P value & \\
\hline \multicolumn{12}{|l|}{2011} \\
\hline Yield & $0.13^{b}$ & $0.37^{\mathrm{a}}$ & $0.53^{\mathrm{a}}$ & $* * *$ & $0.25^{b}$ & $0.32^{\mathrm{ab}}$ & $0.27^{\mathrm{b}}$ & $0.55^{\mathrm{a}}$ & 0.34 & $*$ & n.s. \\
\hline Residues & $0.37^{\mathrm{b}}$ & $0.57^{\mathrm{ab}}$ & $0.81^{\mathrm{a}}$ & $*$ & 0.45 & 0.61 & 0.53 & 0.76 & 0.59 & n.s. & n.s. \\
\hline Weeds & $2.38^{\mathrm{a}}$ & $0.95^{\mathrm{b}}$ & $0.55^{\mathrm{b}}$ & $* * *$ & 1.33 & 1.32 & 1.35 & 1.17 & 1.29 & n.s. & n.s. \\
\hline Burr medic & - & $2.07^{\mathrm{a}}$ & $1.28^{\mathrm{b}}$ & $* *$ & 1.75 & 1.67 & 1.53 & 1.74 & 1.67 & n.s. & n.s. \\
\hline \multicolumn{12}{|l|}{2012} \\
\hline Yield & 0.13 & 0.27 & 0.13 & n.s. & 0.22 & 0.20 & 0.15 & 0.12 & 0.17 & n.s. & n.s. \\
\hline Residues & 0.52 & 0.48 & 0.37 & n.s. & 0.64 & 0.50 & 0.37 & 0.32 & 0.46 & n.s. & n.s. \\
\hline Weeds & 0.67 & 0.39 & 0.42 & n.s. & 0.34 & 0.47 & 0.73 & 0.44 & 0.50 & n.s. & n.s. \\
\hline Burr medic & - & $0.55^{b}$ & $0.95^{\mathrm{a}}$ & $* *$ & 0.68 & 0.76 & 0.83 & 0.72 & 0.75 & n.s. & n.s. \\
\hline
\end{tabular}

NL, control (no living mulch); AS, anticipated sowing; CS, contemporary sowing (at cauliflower transplanting); N0, unfertilised control; SUW, composted municipal solid organic wastes; WDD, anaerobic digestate fertiliser; Org, commercial humified fertiliser; n.s., not significant. a,b Means of living mulch strategies and cauliflower genotypes followed by different letters within rows are significantly different $(\mathrm{P}<0.05) .{ }^{*},{ }^{* *}$, *** Significant at the $\mathrm{P}<0.05, \mathrm{P}<0.01$ and $\mathrm{P}<0.001$, respectively. 


\section{Discussion}

At Monsampolo site, the weather conditions greatly differed between the two years of study, and this difference likely caused the different cauliflower response to the living mulch strategies. In particular, in the rainy and colder year (2011) there were, on average, better productive outcomes than in 2012. Similarly, Cebula et al. (2005) highlighted the effects of climatic conditions on cauliflower crop growth dynamics.

The POS treatment resulted in the highest crop yield and residues dry biomass values in the first year (Table 3), confirming Kolota and Adamczewska-Sowińska (2004) findings. Indeed, the authors observed in leek that delaying the living mulches sowing after the cash crop transplanting did not adversely affect its growth and yield. Another study showed that white clover contemporary sowing to eggplant was favourable for crop growth and yield, whereas perennial non-legume LM (ryegrass) should be sown 3 weeks after planting (AdamczewskaSowińska and Kołota, 2010). Moreover, in our research the highest dry biomass of burr medic was observed by using CON strategy in 2011, whereas no significant differences were observed in the second year between strategies, probably due to the different (less favourable) weather patterns. Therefore, according to Hiltbrunner et al. (2007), a clear inverse trend between the growth of the harvestable crop and that of the cover crop can be inferred in 2011. Similarly, the weed dry biomass was the greatest with CON than POS treatment. These results would suggest that, as a consequence of early sowing, the cover crop was not able to smother weeds establishment and growth, while cauli- flower reduced the yield. In 2012 POS and NL productive results were not significantly different from each other, whereas weeds biomass approximately followed the same behaviour of 2011.

Among the three genotypes, the F1 Emeraude resulted more productive than the two local cultivars, significantly in the first year (Table 3), and it showed no yield differences among sowing time strategies (Figure 2). All the interactions between EM and cover crop sowing strategies showed a smother effect both on weeds and burr medic (Figures 3 and 4). By contrast, the two local cultivars showed a different behaviour depending on the living mulch strategy. In particular, the cv2 showed to be a weaker competitor with weeds than cv1, when combined with CON treatment, whereas the cvl reached yield statistically equal to the EM values in POS treatment. These results confirm the role of genotypes in competitiveness (Mohler, 2007; Zimdahl, 2007) as far as in the effectiveness of living mulches introduction on weed suppression (Masiunas, 1998; Walters, 2011; Kolota and AdamczewskaSowińska, 2013).

At Metaponto site (Experiment 2), in 2011 trial year there were two extreme rainfall events during cauliflower cropping cycle, which greatly influenced its cultivation by destroying the crop production, thus reducing the mean yield. Anyway, according to Collier et al. (2008), also high temperatures could negatively affect cauliflower production. Thus, the next warmer and drier year presented notably low yield results, likely as a consequence of the (opposite) unfavourable climatic conditions. Therefore, the analysis is referred to under-productive outcomes. In fact, in addition to a direct impact on crop development and yield, extreme weather events generally have major impact by physical effects on soil,

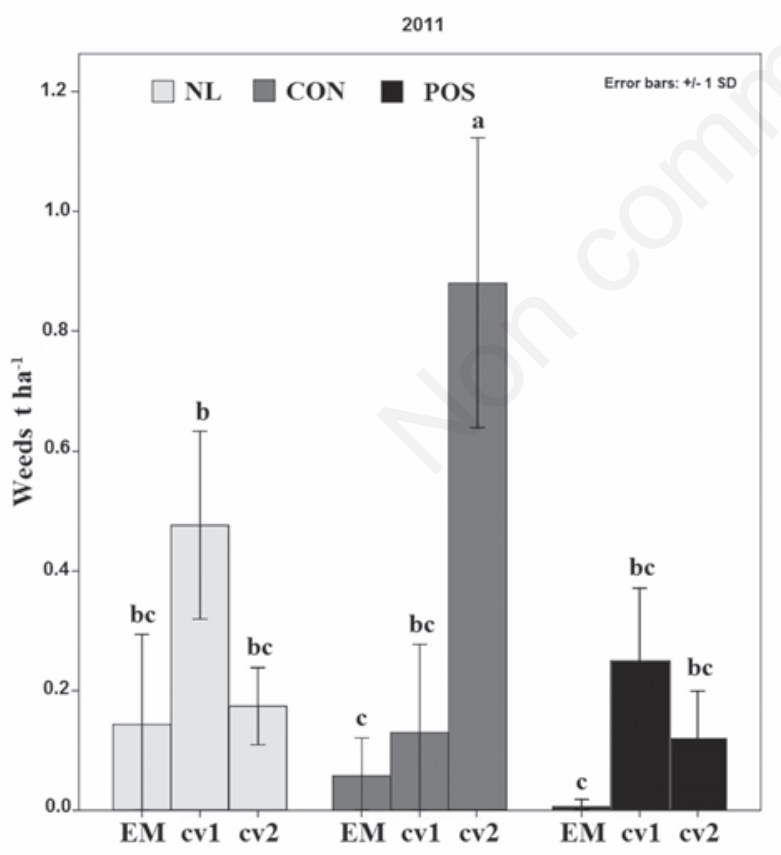

Figure 3. Effect of the interaction between living mulch management strategies and cauliflower genotypes on weeds $\left(\mathrm{t} \mathrm{ha}^{-1}\right)$ in 2011 trial year. The bars with different letters are significantly different $(P<0.05)$. NL, no living mulch control; CON, early sowing, at cauliflower transplanting; POS, late sowing, three weeks after cauliflower transplanting; EM, Emeraude F1 Hybrid; cv1 and cv2, open-pollinated, locally adapted cultivars.

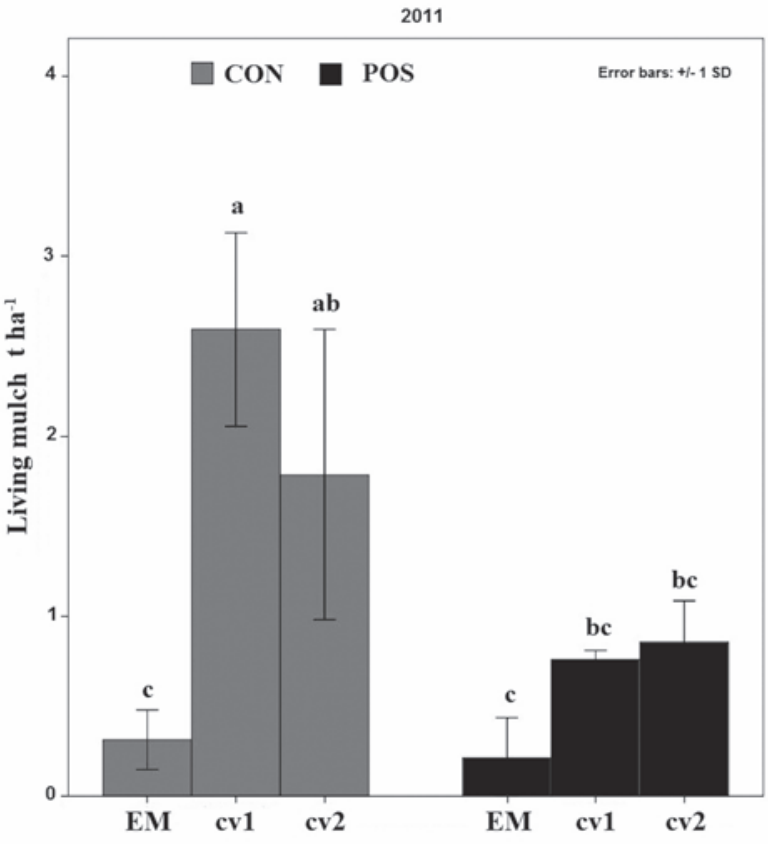

Figure 4. Effect of the interaction between living mulch management strategies and cauliflower genotypes on burr medic $\left(\mathrm{tha}^{-1}\right)$ in 2011 trial year. The bars with different letters are significantly different $(P<0.05)$. NL, no living mulch control; CON, early sowing, at cauliflower transplanting; POS, late sowing, three weeks after cauliflower transplanting; EM, Emeraude F1 Hybrid; cv1 and cv2, open-pollinated, locally adapted cultivars. 
either because of drought or waterlogging (Collier et al., 2008).

In 2011, both AS and CS determined higher yields than NL treatment (no weeding). On the contrary, a strong weed biomass decrease in the AS and CS treatments (by 60\% and 77\% compared to NL, respectively) was observed. This was in agreement with Jędrszczyk et al. (2005) who found that cultivation of white head cabbage with a white clover as living mulch determined weed biomass reduction by $96 \%$. However, no significant weed biomass reduction was recorded in the AS treatment compared to the CS one, despite the higher LM biomass in AS plots. Conversely, Barberi et al. (2008) showed a proportional decrease of weeds total biomass in relation to the amount of living mulch biomass in spinach cultivation. The inverse trend, between the growth of the harvestable crop and that of the cover crop highlighted by Hiltbrunner et al. (2007), was observed for CS treatment and also corresponded to a reduced weeds performance. Therefore, the time of mulches sowing should be chosen carefully to ensure optimal soil covering (MüllerSchärrer and Potter, 1991). In the same year, the comparable yield results of SUW with Org treatment, indicated that both the tested fertilisers may represent a feasible option for farmers who can select them in accordance to the availability of these fertiliser at local level. Similarly, Montemurro et al. (2005) found that SUW can serve as a N source for tomato crop, increasing total yield by more than $6 \% \mathrm{com}$ pared to untreated control. Despite this result, no difference among fertilisers was found comparing weed and burr medic biomasses, in contrast with the findings of other authors showing improved weed control as a consequence of fertilisation (Evans et al., 2003; Brainard and Bellinder, 2004).

Moreover, in 2012 the climatic conditions seem to have levelled out all the observed results, except the burr medic biomass. The significantly lower biomass value in AS treatment than in CS suggested an effect of the high temperatures and low rainfall recorded on September 2012 on the living mulch establishment.

\section{Conclusions}

The results obtained in our study demonstrated that vegetable cropping systems designed in accordance to agro-ecological principles and by combining different agronomic strategies (including selection of both sowing time of ASC and genotype of the harvestable crop) are able to produce fairly good yields influencing, at the same time, weed presence and development. Furthermore, the differences recorded between the two experiments also highlighted the need to diversify the agronomic strategies and to tailor them to the different environments.

Further researches aiming to evaluate the feasibility of different living mulches (e.g., mixing of different cover crops) introduction and their effectiveness in Mediterranean organically managed agro-ecosystems should be highly encouraged. This could help to evaluate the potential of the technique to provide agro-ecological services in the short and long-term periods.

\section{References}

Adamczewska-Sowińska K, Kołota E, 2010. Yielding and nutritive value of field cultivated eggplant with the use of living and synthetic mulches. Acta Sci. Pol. Hort. Cultus 9:191-9.

Barberi P, Bigongiali F, Antichi D, Carlesi S, Fontanelli M, Fiasconi C, Lulli L, 2008. Innovative crop and weed management strategies for organic spinach: crop yield and weed suppression. In: Cultivating the future based on science. Vol. 1: Organic crop production. Proc. 2nd Sci. Conf. Int. Soc. Organic Agric. Res. (ISOFAR), 18-20 June, Modena, Italy, pp 252-255.

Brainard DC, Bellinder RR, 2004. Weed suppression in broccoli-winter rye intercropping systems. Weed Sci. 52:281-90.

Bilalis D, Papastylianou P, Konstantas A, Patsiali S, Karkanis A, Efthimiadou A, 2010. Weed-suppressive effects of maize-legume intercropping in organic farming. Int. J. Pest. Manage. 56:173-81.

Campanelli G, Canali S, 2012. Crop production and environmental effects in conventional and organic vegetable farming systems: the case of a long-term experiment in Mediterranean conditions (Central Italy). J. Sustain. Agr. 36:599-619.

Campiglia E, Mancinelli R, Radicetti E, 2011. Influence of no-tillage and organic mulching on tomato (Solanum Lycopersicum L.) production and nitrogen use in the mediterranean environment of central Italy. Sci. Hortic. 130:588-98.

Carof M, de Tourdonnet S, Saulas P, Le Floch D, Roger-Estrade J, 2007. Undersowing wheat with different living mulches in a no-till system. I. Yield analysis. Agron. Sustain. Dev. 27:347-56.

Cebula S, Kalisz A, Kunicki E, 2005. The course of growth and yielding of white and green cauliflower cultivated in two terms for autumn production. Folia Hort. 17:23-35.

Collier R, Fellows J, Adams S, Semenov M, Thomas B, 2008. Vulnerability of horticultural crop production to extreme weather events. Aspects Appl. Biol. 88:3-13.

Driouech N, Abou Fayad F, Ghanem A, Al-Bitar L, 2008. Agronomic performance of annual self-reseeding legumes and their self-establishment potential in the Apulia region of Italy. In: 16th IFOAM Organic World Congress, June 16-20, Modena, Italy. Available from: http://orgprints.org/view/projects/conference.html

Evans SP, Knevic SZ, Lindquist JL, Shapiro CA, Blankenship EE, 2003. Nitrogen application influences the critical period for weed control in corn. Weed Sci. 51:408-17.

Fageria NK, Baligar VC, Bailey BA, 2005. Role of cover crops in improving soil and row crop productivity. Commun. Soil Sci. Plant Anal. 36:2733-57.

Hartwig NL, Ammon HU, 2002. Cover crops and living mulches. Weed Sci. 50:688-99.

Hiltbrunner J, Liedgens M, Bloch L, Stamp P, Streit B, 2007. Legume cover crops as living mulches for winter wheat: components of biomass and the control of weeds. Eur. J. Agron. 26:21-9.

Jędrszczyk E, Poniedziałek M, S kara A, 2005. Effect of living mulch on white head cabbage (Brassica oleracea var. capitata subvar. alba L.) yielding. Folia Hort. 17:29-36.

Kolota E, Adamczewska-Sowińska K, 2004. The effects of living mulches on yield, overwintering and biological value of leek. Acta Hort. (ISHS) 638:209-14.

Kolota E, Adamczewska-Sowińska K, 2013. Living mulches in vegetable crops production: perspectives and limitations (A reviev). Acta Sci. Pol. Hort. Cultus 12:127-42.

Masiunas JB, 1998. Production of vegetables using cover crop and living mulches - a review. J. Veg. Soil Prod. 4:11-31.

Mazzoncini M, Sapkota TB, Bàrberi P, Antichi D, Risaliti R, 2011. Longterm effect of tillage, nitrogen fertilization and cover crops on soil organic carbon and total nitrogen content. Soil Till. Res. 114:165-74.

Mohler CL, 2007. Enhancing the competitive ability of crops. In: M. Liebman, C.L. Mohler and C.P. Staver (eds.), Ecological management of agricultural weeds. Cambridge University Press, Cambridge, UK, pp 269-321.

Montemurro F, Convertini G, Ferri D, Maiorana M, 2005. MSW compost application on tomato crops in Mediterranean conditions: effects on agronomic performance and nitrogen utilization. Compost Sci. Util. 13:234-42. 
Montemurro F, Fiore A, Campanelli G, Tittarelli F, Ledda L, Canali S, 2013. Organic fertilization, green manure, and vetch mulch to improve organic zucchini yield and quality. Hort. Sci. 48:1027-33.

Müller-Schärrer H, Potter CA, 1991. Cover plants in field grown vegetables: prospects and limitations. pp 599-604 in Proc. Brighton Crop Protection Conf. - Weeds.

Soil Survey Staff, 1999. Soil taxonomy. Agriculture Handbook 436. USDA-NRCS, Washington, DC, USA.

Teasdale JR, Brandsæter LO, Calegari A, Skora Neto F, 2007. Cover crops and weed management. In: M.K. Upadhyaya and R.E. Blackshaw (eds.), Non-chemical weed management. CAB International, Wallingford, UK, pp 49-64.
UNESCO-FA0, 1963. Ecological study of the Mediterranean zone. Bioclimatic map of the Mediterranean zone, explanatory notes. NS.162/III. 22/A, Paris, France.

Walters SA, 2011. Weed management systems for no-tillage vegetable production. In: S. Soloneski and M.L. Larramendy (eds.), Herbicides, theory and applications. InTech, Rijeka, Croatia, pp 17-40.

Wezel A, Casagrande M, Celette F, Vian JF, Ferrer A, Peigné J, 2014. Agroecological practices for sustainable agriculture. A review. Agron. Sustain. Dev. 34:1-20.

Zimdahl R, 2007. Weed-crop competition: a review. 2nd ed. Blackwell Publishing, New York, NY, USA, pp 146-166. 